\title{
The contribution of wood products to carbon sequestration in Portugal
}

\author{
Ana Cláudia DiAS*, Margarida LOURO, Luís ARROJA, Isabel CAPELA \\ Department of Environment and Planning, University of Aveiro, 3810-193 Aveiro, Portugal
}

(Received 13 April 2004; accepted 5 January 2005)

\begin{abstract}
Carbon sequestration in wood products in Portugal was estimated for the 1990-2000 period using two accounting approaches: the stock-change and the atmospheric-flow. Calculations rely on historical data for production and trade of wood products, and on typical values for their lifetimes. Carbon sequestration in wood products, calculated by the stock-change approach, increased from $310 \mathrm{Gg} \mathrm{C}^{-1} \mathrm{in}_{1990}$ to $611 \mathrm{Gg} \mathrm{C} \mathrm{yr}^{-1}$ in 2000 . The estimates of carbon sequestration using the atmospheric-flow approach, in the same period, varied from $322 \mathrm{Gg} \mathrm{C} \mathrm{yr}^{-1}$ to $783 \mathrm{Gg} \mathrm{C} \mathrm{yr}^{-1}$, and do not show the same increasing trend given by the stock-change approach, as they depend not only on the change in the stocks of wood products but also on their trade. The sensitivity analysis performed shows that the results are significantly affected by the parameters related with the lifetime of the products, the carbon fraction in paper and the biomass conversion factor.
\end{abstract}

carbon sequestration / wood products / stock-change approach / atmospheric-flow approach / Portugal

Résumé - Contribution des produits du bois à la séquestration du carbone au Portugal. La séquestration de carbone par les produits du bois au Portugal a été estimée pour la période 1990-2000, par deux approches de calcul: le stock-change et l'atmospheric-flow. Les calculs se basent sur des données historiques de production et de commerce de produits du bois, ainsi que sur les durées de vie caractéristiques de ces produits. La séquestration de carbone par les produits du bois, calculée par l'approche stock-change, a augmenté de $310 \mathrm{Gg} \mathrm{C}^{-1}$ à $611 \mathrm{Gg} \mathrm{C}^{-1}$ entre 1990 et 2000. La séquestration de carbone, estimée par l'approche atmospheric flow, pour la même période, a varié entre $322 \mathrm{Gg} \mathrm{C}$ an ${ }^{-1}$ à $783 \mathrm{Gg} \mathrm{C}$ an ${ }^{-1}$, et ne présente pas la même tendance d'augmentation obtenue par l'approche stock-change, vu qu'elle dépend non seulement de la variation des stocks des produits du bois, mais aussi du commerce des produits du bois. Une analyse de sensitivité réalisée montre que les résultats sont significativement affectés par les paramètres liés à la durée de vie des produits, la fraction de carbone dans le papier et le facteur de conversion de la biomasse.

séquestration de carbone / produits du bois / stock-change approach / atmospheric-flow approach / Portugal

\section{INTRODUCTION}

Wood products are a component of the carbon cycle for the forest sector. Part of the carbon contained in harvested roundwood is released to the atmosphere in the same year or within a couple of years, by the decomposition and burning of fuelwood, wood processing residues, and short-lived wood products. Another part of the carbon remains stored in long-lived wood products in use, which may persist for decades to centuries [24]. The total lifetime of wood products may be extended if they are disposed off in landfills, where they are only partially decomposed, forming a permanent carbon sink [30]. The worldwide carbon sequestration in wood products was estimated by Winjum et al. [45] as about $139 \mathrm{Tg} \mathrm{C} \mathrm{yr}^{-1}$ in 1990. Wood products can also mitigate carbon emissions from fossil fuels when they are burnt to produce energy or when they substitute alternative materials such as concrete, steel or ceramic materials used in the construction and interior works of buildings [44].

The current methodology used in the preparation of national greenhouse gas inventories under the UNFCCC (United
Nations Framework Convention on Climate Change), the Revised 1996 IPCC (Intergovernmental Panel on Climate Change) Guidelines [20-22], assumes as default, that all carbon in the biomass harvested is oxidised in the removal year, neglecting the carbon sink provided by the wood products. However, the IPCC Guidelines allow the inclusion of this sink in the national inventory if a country can document that existing stocks of long term products are in fact increasing [22], but it does not provide an accounting methodology.

Three alternative approaches for accounting carbon in wood products were proposed: the stock-change approach, the production approach, and the atmospheric-flow approach [4, 29]. They have been applied and compared in several studies [12, $13,16,25,26,31,36,41,45]$. The approaches differ in the way carbon emissions from traded wood and wood products are allocated to consuming and producing countries. The stockchange approach estimates the net change in carbon stocks in the forest and in the wood products pool, within national boundaries. Stock changes in forests are accounted for in the producing country, whereas stock changes in wood products are accounted for in the consuming country. The production

* Corresponding author: aclaudia@dao.ua.pt 
Table I. Biomass conversion factors, bark fractions and carbon fractions for different categories of wood and wood products. Default values are from Winjum et al. [45]; minimum and maximum values were used in the sensitivity analysis.

\begin{tabular}{|c|c|c|c|c|c|c|c|c|c|}
\hline \multirow[t]{2}{*}{ Wood/wood product } & \multicolumn{3}{|c|}{$\begin{array}{l}\text { Biomass conversion factor } \\
\qquad\left(\mathrm{Mg} \mathrm{m}^{-3}\right)\end{array}$} & \multicolumn{3}{|c|}{ Bark fraction } & \multicolumn{3}{|c|}{ Carbon fraction } \\
\hline & Default & Min & $\operatorname{Max}$ & Default & Min & Max & Default & Min & Max \\
\hline \multicolumn{10}{|l|}{ Industrial roundwood } \\
\hline Conifer & 0.40 & 0.36 & 0.67 & 0.11 & 0.11 & 0.43 & 0.50 & 0.4627 & 0.552 \\
\hline Non-conifer & 0.50 & 0.47 & 0.65 & 0.13 & 0.13 & 0.25 & 0.50 & 0.4627 & 0.552 \\
\hline Fuelwood & 0.45 & 0.41 & 0.66 & 0.12 & 0.12 & 0.34 & 0.50 & 0.4627 & 0.552 \\
\hline \multicolumn{10}{|l|}{ Sawnwood } \\
\hline Conifer & 0.42 & 0.36 & 0.67 & - & - & - & 0.50 & 0.4627 & 0.552 \\
\hline Non-conifer & 0.53 & 0.47 & 0.65 & - & - & - & 0.50 & 0.4627 & 0.552 \\
\hline Wood-based panels & 0.52 & 0.52 & 0.70 & - & - & - & 0.50 & 0.40 & 0.50 \\
\hline \multicolumn{10}{|c|}{ Other industrial roundwood } \\
\hline Conifer & 0.56 & 0.36 & 0.67 & - & - & - & 0.50 & 0.4627 & 0.552 \\
\hline Non-conifer & 0.64 & 0.47 & 0.65 & - & - & - & 0.50 & 0.4627 & 0.552 \\
\hline Paper and paperboard & - & - & - & - & - & - & 0.50 & 0.30 & 0.50 \\
\hline
\end{tabular}

approach also estimates net changes in carbon stocks in the forest and in the wood products pool. Stock changes in forests are accounted for in the producing country, as well as the carbon contained in exported wood products. The atmospheric-flow approach estimates the flows of carbon between the biosphere and the atmosphere within national boundaries. Uptake of carbon from forest growth is accounted for in the producing country, while carbon emissions from the oxidation of wood or wood products are accounted for in the consuming country.

The increasing production and consumption of wood products in Portugal [10] indicate that they may be a carbon sink, provided that new products are additional to the existing ones. In this study, carbon sequestration in wood products in Portugal was estimated for the 1990-2000 period using both the stockchange approach and the atmospheric-flow approach. The production approach was not attempted, due to the lack of reliable data on the way domestically grown wood and wood products are processed, used and disposed off in the countries where they are consumed. Such estimates are highly uncertain, as they must be based on approximations and assumptions.

Within each accounting approach (i.e., the conceptual framework) there may be more than one estimation method (i.e., the calculation framework), which can be applied with different levels of complexity, depending on data availability. In this study, it was adopted the method described by Winjum et al. [45], which is based on a lifetime analysis using some simplified assumptions. It relies on statistical data of production and trade of wood and wood products available in the FAO (Food and Agriculture Organization) forestry database [10] and provides default values for the conversion factors and lifetimes needed in the calculations. Furthermore, a sensitivity analysis was carried out in order to assess the effect of modifying these default values, and to identify those contributing to the major changes in the estimates of carbon sequestration.

\section{MATERIALS AND METHODS}

In the stock-change approach, carbon sequestration is estimated as the sum of the change in carbon stocks in forest and the change in carbon stocks in wood products consumed in the country. In the atmospheric-flow approach, carbon sequestration is equal to the one estimated by the stock-change approach, plus the net export of carbon in wood and wood products (as demonstrated by Flugsrud et al. [12]). The change in carbon stocks in the forest ecosystem, which is similar in both approaches, was excluded from this analysis. Only the additional sequestration (or emission) in relation to the IPCC default approach was accounted for.

The change in carbon stocks in wood products was calculated as the difference between carbon contained in wood products consumed in a reference year, not decaying in that year, and inherited emissions from wood products consumed in previous years.

The consumption of wood products, as well as the net export term in the atmospheric-flow approach, were derived from the FAO database [10], which provides data for the 1961-2000 period of production, import and export of roundwood (industrial roundwood and fuelwood) and semi-finished wood products (sawnwood, wood-based panels, other industrial roundwood, and paper and paperboard).

Because the data for roundwood, sawnwood, wood-based panels and other industrial roundwood are reported in volume, conversion factors are required to express these products in terms of dry mass. In the case of roundwood, as the volume is inside-bark, a bark fraction must be also added to estimate the total volume of stem. The conversion factors and the bark fractions are those used by Winjum et al. [45] and are given in the "default" column of Table I. The carbon content in the wood was obtained by assuming a common carbon fraction of 0.5 in the dry mass (Tab. I).

Wood products were divided into two groups according to their lifetimes. Short-lived products have a lifetime lower than five years and were assumed to decay immediately. The remaining are long-lived products and were assumed to decay at a constant decay rate established for each product category. This decay rate is the inverse of the lifetime: a decay rate of $0.01 \mathrm{yr}^{-1}$ means a lifetime of 100 years. The fraction of long-lived products and the annual decay rate for each product 
Table II. Fractions of long-lived products and annual decay rates for different categories of wood products. Default values are from Winjum et al. [45]; minimum and maximum values were used in the sensitivity analysis.

\begin{tabular}{lccccccc}
\hline Wood product & \multicolumn{3}{c}{ Fraction of long-lived products } & & \multicolumn{3}{c}{ Annual decay rate $\left(\mathrm{yr}^{-1}\right)$} \\
\cline { 2 - 4 } \cline { 5 - 7 } & Default & Min & Max & & Default & Min & Max \\
\hline Sawnwood & 0.8 & 0.60 & 0.8 & & 0.01 & 0.01 & 0.02 \\
Wood-based panels & 0.9 & 0.67 & 0.9 & & 0.02 & 0.02 & 0.04 \\
Other industrial roundwood & 0.7 & 0.53 & 0.7 & & 0.04 & 0.04 & 0.08 \\
Paper and paperboard & 0.6 & 0.45 & 0.6 & & 0.01 & 0.01 & 0.02 \\
\hline
\end{tabular}

category used in this study were taken from Winjum et al. [45] for temperate regions ("default" column in Tab. II). These parameters take into account not only the use period of the wood products, but also the waste period in landfills. Inherited emissions resulting from the decay of wood products consumed before 1961 were assumed to be negligible.

In the sensitivity analysis, the default parameters were allowed to vary within realistic, or in some cases, probable ranges. Thus, maximum and minimum values were selected for the different parameters (Tabs. I and II) and were combined in order to obtain maximum and minimum estimates of the carbon sequestration in wood products.

The biomass conversion factor for industrial roundwood ranged from 0.36 to $0.67 \mathrm{Mg} \mathrm{m}^{-3}$ for conifers [6] and from 0.47 to $0.65 \mathrm{Mg} \mathrm{m}^{-3}$ for non-conifers [43]. These values are typical for the conifer Pinus pinaster and for the non-conifer Eucalyptus globulus, which are the most important exported species in Portugal. The same ranges were adopted for the imported species, mainly from tropical and temperate forests, since the values reported in the literature $[39,40]$ are of the same magnitude. The average values for conifers and non-conifers were used for fuelwood. The minimum and maximum biomass conversion factors used for industrial roundwood were also adopted for sawnwood and other industrial roundwood, neglecting the likely increase in the biomass conversion factor due to the shrinkage of wood. The biomass conversion factor of wood-based panels varies between $0.52 \mathrm{Mg} \mathrm{m}^{-3}$ and $0.93 \mathrm{Mg} \mathrm{m}^{-3}$ [25], depending on the type of panel (veneer sheets, plywood, particle board, hardboard, medium density fibreboard and insulating board). The default value of $0.52 \mathrm{Mg} \mathrm{m}^{-3}$ was kept as a minimum value, and the value used by Ford-Robertson et al. [13] for panels in general, $0.7 \mathrm{Mg} \mathrm{m}^{-3}$, was considered as a maximum.

The maximum values of the bark fraction for conifers and nonconifers were derived respectively from the highest bark fraction observed in $P$. pinaster and E. globulus. For $P$. pinaster this parameter ranges from 0.25 to $0.43[8,42]$ of the volume of stemwood insidebark, while for E. globulus varies between 0.18 and 0.25 [15]. Because default values are smaller than these, they were used as minimum values. Fuelwood was assumed to have a bark fraction equal to the average of the values taken for conifers and non-conifers.

The carbon fraction in industrial roundwood and fuelwood ranged from 0.4627 to 0.552 [28]. The same fractions were employed for sawnwood and other industrial roundwood as wood is not modified. For wood-based panels and paper and paperboard, a smaller carbon fraction is expected, since they incorporate materials other than wood. For these wood products, the maximum carbon fraction was the default value, 0.5 , and the minimum value was set to 0.4 for wood-based panels [25] and to 0.3 for paper and paperboard [2].

The fraction of paper and paperboard allocated to long-lived products was assumed to include the printing and writing paper in use plus the paper and paperboard disposed in landfills and averaged approximately 0.45 in Portugal, between 1961 and 2000 (printing and writing paper accounted for 15 to $35 \%$ of the total consumption of paper and paperboard [7,8], and 15 to $40 \%$ of the discarded paper and paperboard was landfilled $[18,19,38])$. This value was adopted for the minimum value of the fraction allocated to long-lived products and the default value was used for the maximum value. For sawnwood and woodbased panels, the default values used for the fraction allocated to longlived products are similar to the average values that prevailed in Portugal in the 1961-2000 period. In fact, some studies [1, 9, 33] suggest that about 75 to $90 \%$ of the sawnwood and 80 to $90 \%$ of the wood-based panels consumed in Portugal over the 1961-2000 period were used to produce potentially long-lived products, such as furniture and construction wood (for these kinds of products, the fractions going to landfills are expected to be very small). In this case, a conservative procedure was adopted and, thus, the default values were used as maximum values and the minimum values were obtained by decreasing the default values by the same percentage obtained for paper and paperboard, i.e., 25\%. The same procedure was applied for the other industrial roundwood as information about the fraction allocated to long-lived products is not available for the Portuguese conditions.

It is difficult to obtain measured values for the annual decay rates of long-lived products, as they are not directly reported by any statistical source. Thus, they are mainly estimated based on assumptions and wood-using practices. The ranges of the lifetimes (the inverse of the annual decay rates) of long-lived products found in the literature vary widely, and, in general, the default values used in this study fit well in those ranges. The average lifetime of long-lived sawnwood varies from 15 years if it is used for furniture [5] to 145 years if it is used for residential construction [41]. A variation between 15 years [37] and 90 years [27] was found for the average lifetime of long-lived woodbased panels. For long-lived other industrial wood, the average lifetime ranges from 10 years if it is used for fences or gates [40] to 50 years if it is used for poles [25]. The total lifetime of long-lived paper is more uncertain than those of solidwood products since it includes the time paper lasts in use and in landfills (as referred previously, the amount of solidwood products disposed in landfills in Portugal are expected to be insignificant). The average lifetime of long-lived paper in use ranges from 6 to 20 years [27], while paper in landfills can last much more. In fact, a part of landfilled paper decays within 5 to 30 years [23], but another part, amounting to 33 to $84 \%$ of the landfilled paper $[23,30]$, is very resistant to decay. In conclusion, it seemed to be reasonable to assume that the maximum values of the annual decay rates are the double of the default values (and, consequently, the lifetimes were reduced to half of the default values). The minimum values of the annual decay rate were assumed to be equal to the default values. A decrease in the annual decay rates was excluded from the sensitivity analysis due to the lack of even more remote data needed to calculate inherited emissions. Due to the limited time coverage by the FAO database, when wood products have a lifetime longer than 40 years, inherited emissions from the decay of wood products consumed prior to 1961 will be underestimated.

\section{RESULTS}

Wood products were a net sink of carbon in Portugal throughout the studied period, regardless of the accounting 


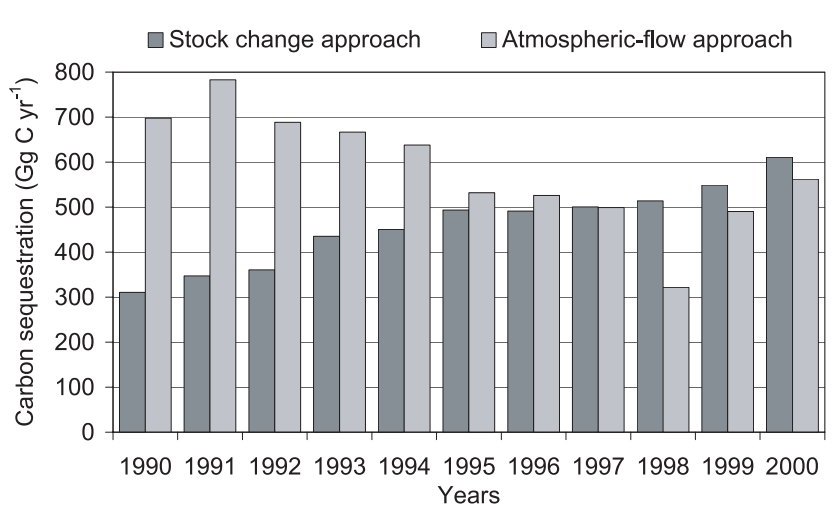

Figure 1. Carbon sequestration estimated by both the stock-change and the atmospheric-flow approaches.

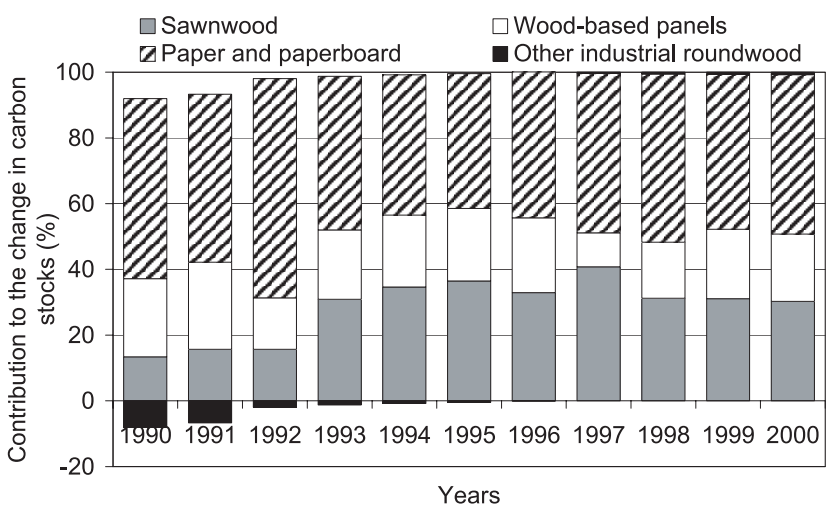

Figure 2. Relative contribution of each wood product category to the total change in carbon stocks.

approach (Fig. 1). Carbon sequestration estimated by the stockchange approach has been increasing from $310 \mathrm{Gg} \mathrm{C} \mathrm{yr}^{-1}$, in 1990 , to $611 \mathrm{Gg} \mathrm{C} \mathrm{yr}^{-1}$, in 2000. The relative contribution of each wood product category to the total change in carbon stocks (equal to the carbon sequestration given by the stock-change approach) is shown in Figure 2. These results are better understood if complemented with the evolution of the consumption of wood products in Portugal, shown in Figure 3. Paper was the most important carbon sink during the whole period, with a relative contribution to the total carbon sequestration varying from $41 \%$ in 1995 , to $67 \%$ in 1992 . This is due to the fact that paper was the most consumed product in the 1990-2000 period. Besides, its consumption has been increasing exponentially, so that the corresponding inherited emissions are relatively small. Sawnwood ranked second in the contribution to the total carbon sequestration, except for the 1990-1992 period, with a share that ranges from $13 \%$ in 1990 , to $41 \%$ in 1997 . This is the result of its important consumption in the 1990-2000 period, in spite of the inherited emissions, which are relatively large in this case. However, the inherited emissions are likely underestimated, since they cannot be calculated for the full lifetime of sawnwood. The share of wood-based panels to the total carbon sequestration varied from $10 \%$ in 1997 to $27 \%$ in 1992 . The

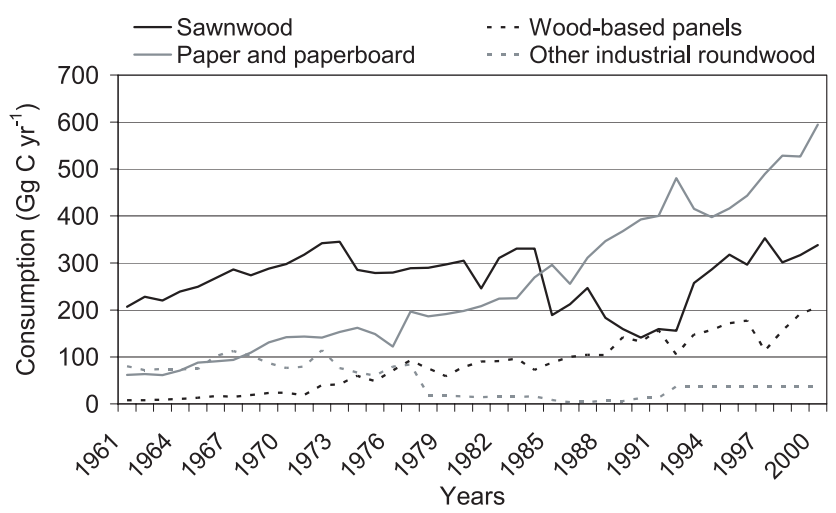

Figure 3. Consumption of wood products in Portugal.

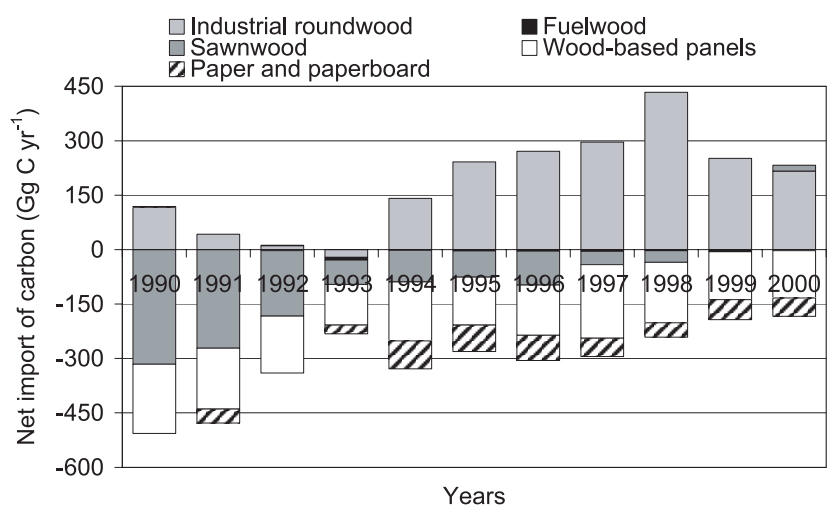

Figure 4. Portuguese net import of carbon in wood and wood products; positive values represent net import and negative values represent net export.

other industrial roundwood showed a very small contribution of about $1 \%$ to the total carbon sequestration between 1997 and 2000. Before that period it was a net source of carbon.

The estimates of carbon sequestration by the atmosphericflow approach, which vary from $322 \mathrm{Gg} \mathrm{C} \mathrm{yr}^{-1}$ to $783 \mathrm{Gg} \mathrm{C} \mathrm{yr}^{-1}$ in the 1990-2000 period, do not show the same increasing trend given by the stock-change approach (Fig. 1). This is due to the fact that they depend not only on the change in the stocks of wood products but also on the import and export of wood and wood products. Figure 4 shows the net import of carbon in wood and wood products, in which positive values represent net import and negative values represent net export. With a few exceptions, Portugal was a net importer of roundwood and a net exporter of the different product categories. The estimates of carbon sequestration with the atmospheric-flow approach were higher than the ones obtained with the stock-change approach from 1990 to 1996, as a result of a net export of carbon, mainly as sawnwood and wood-based panels. After 1997, Portugal was a net importer of carbon as the import of carbon in industrial roundwood exceeds the export of carbon in wood products.

The results of the sensitivity analysis are presented in Figures 5 and 6 , respectively for the stock-change and the atmospheric-flow approaches. The grey area in the graphics is 


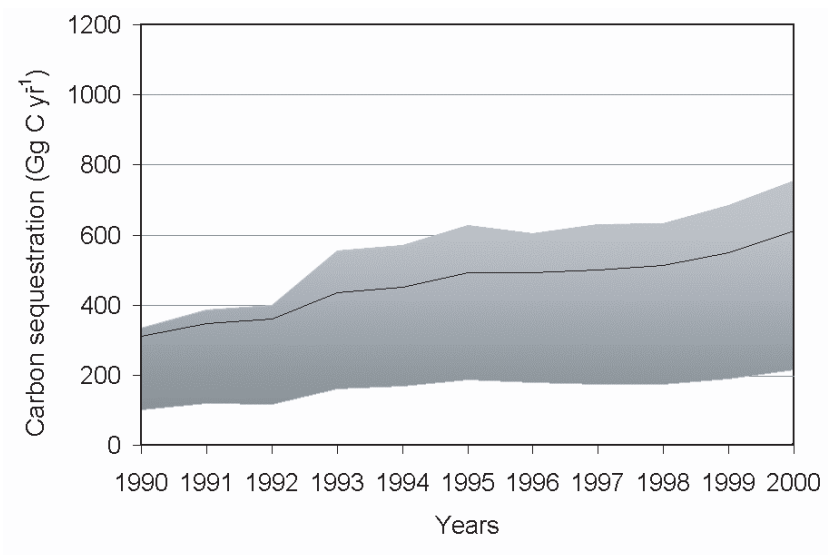

Figure 5. Carbon sequestration estimated by the stock-change approach in the sensitivity analysis; the grey area is delimited by the minimum and maximum estimates.

delimited by the minimum and maximum estimates of carbon sequestration.

Even in the minimum estimate of the stock-change approach, wood products were still a carbon sink. The minimum estimate of this approach was on average about $65 \%$ smaller than the default estimate, during the 1990-2000 period. The parameters contributing most to this reduction were the annual decay rates, the fraction allocated to long-lived products and the carbon fraction in paper and paperboard, which were changed in 100\%, 25\% and $40 \%$ respectively. Changing each one of these parameters alone, lead to an average decrease in carbon sequestration of about $32 \%, 25 \%$ and $21 \%$ respectively. The individual variation of the remaining parameters resulted in an average decrease in carbon sequestration smaller than $4 \%$. The maximum estimate of the stock-change approach exceeded the default estimate in about $20 \%$ on average in the whole period. The largest contributions came from the biomass conversion factor of sawnwood and wood-based panels, which respectively increased the carbon sequestration in about $10 \%$ and $7 \%$ on average when were changed alone. The minimum estimate differs more from the default estimate than the maximum estimate, because in the latter, some parameters, including the most influential, are kept equal to the default parameters.

In the minimum estimate of the atmospheric-flow approach, wood products behave like a small sink after 1995, and they became into a carbon source in 1998. In this estimate the average carbon sequestration during the period decreased about $80 \%$ in relation to the default estimate. The decrease in carbon sequestration after 1995 was larger than before that year. This trend is mainly caused by the largest influence of both the biomass conversion factor and the bark fraction of industrial roundwood after 1995, due to an higher net import of industrial roundwood. The annual decay rates, the fraction allocated to long-lived products and the carbon fraction in paper and paperboard were once again the parameters that produced the largest changes. When they were changed individually, an average decrease in carbon sequestration of about $27 \%, 21 \%$ and $20 \%$ respectively was observed. Furthermore, as mentioned earlier,



Figure 6. Carbon sequestration estimated by the atmospheric-flow approach in the sensitivity analysis; the grey area is delimited by the minimum and maximum estimates.

the change in the biomass conversion factor of industrial roundwood had also an important contribution to the decrease of carbon sequestration after 1995. This decrease was particularly significant in 1998, where the individual change of this parameter resulted in a decrease of carbon sequestration of about $40 \%$. For the maximum estimate of the atmospheric-flow approach, carbon sequestration in the whole period was on average about 43\% larger than for the default estimate. The biomass conversion factor of sawnwood and wood-based panels originated the major increases in carbon sequestration (22\% and $16 \%$ on average, respectively) when they were changed individually.

Under the atmospheric-flow approach the difference between the estimates obtained in the sensitivity analysis and the default estimate was on average larger than under the stockchange approach, due to the additional uncertainty caused by the extra term concerning net export.

\section{DISCUSSION}

Wood products are often estimated as being a small carbon sink in comparison with other parts of the forest sector [12,32]. This was not the case of Portugal during the period analyzed in this study, where wood products provided a carbon sink comparable with the one of forest. From 1990 to 1994, carbon sequestration in forest was even smaller than in wood products. According to the last greenhouse gas inventory submitted to the UNFCCC [11], carbon sequestration in forest equalled $1 \mathrm{Gg} \mathrm{C} \mathrm{yr}^{-1}$ in 1990 and $587 \mathrm{Gg} \mathrm{C} \mathrm{yr}^{-1}$ in 2000 , achieving a maximum of $643 \mathrm{Gg} \mathrm{C} \mathrm{yr}^{-1}$ in 1999. The estimated carbon sequestration in wood products was equivalent to almost $3 \%$ of the total carbon equivalent emissions (excluding forestry) in Portugal in 2000, which amounted to $22430 \mathrm{Gg} \mathrm{C} \mathrm{yr}^{-1}$. This percentage is similar to the one obtained globally [45].

Jäkel et al. [26] also estimated the carbon sink in wood products in Portugal using the same approaches as this study. They reported a carbon sink of zero and $500 \mathrm{Gg} \mathrm{Cyr}^{-1}$ in 1990, using respectively the stock-change and the atmospheric-flow approaches, and about $300 \mathrm{Gg} \mathrm{C} \mathrm{yr}^{-1}$ in 1998 with the two 
approaches. These values show a general trend to be smaller than the ones estimated in this study using default parameters, as a result of the use of a smaller carbon fraction in paper $(0.25)$ and of the inclusion of inherited emissions before 1961 by assuming an exponential growth of the consumption of wood products in that period.

The simplification made in this study, by assuming that inherited emissions resulting from the decay of wood products consumed before 1961 are negligible, resulted in a likely overestimation of carbon sequestration in sawnwood, wood-based panels and paper and paperboard, as these products have default lifetimes of respectively 100, 50 and 100 years, which are longer than the period covered by the FAO database ( 40 years). The minimum estimate of the sensitivity analysis is also likely overestimated with respect to sawnwood and paper and paperboard, due to the assumed lifetime of 50 years. However, this simplification in the calculations has only a small effect in the estimates of carbon sequestration in wood-based panels and paper and paperboard, since their consumption prior to 1961 is expected to be small (Fig. 3). By the contrary, the consumption of sawnwood prior to 1961 is expected to be significant, given the consumption in 1961 (Fig. 3), which results on important inherited emissions, mainly when the lifetime is of 100 years. In this case, the emissions associated with more than half of the lifetime are not accounted for.

Another simplification of the method used in this study was the consideration of carbon accumulation in finished products (such as furniture, doors and books) equal to carbon accumulated at the level of semi-finished products, because statistical data of production of finished products are not systematically collected for Portugal. This simplification can originate a misleading picture if finished products are traded, because they remain allocated to the producing country. However, this has a limited effect in Portugal as the amount of carbon in traded finished products is small compared with the amount of carbon in consumed semi-finished products [17].

The estimation method used here is based on many simplifications and assumptions, which introduce some uncertainty. The results of the sensitivity analysis demonstrate that some parameters significantly affect the estimates of carbon sequestration in wood products. This was the case of the annual decay rates, which have an high uncertainty, specially if the decay in landfills is included. More robust values for the annual decay rates can be obtained by performing direct inventories of the stock of wood products [3, 14, 34, 35] at different years. For example, Pingoud et al. [35] estimated the average decay rate of wood products used in the Finnish buildings, fitting the stocks obtained with a dynamic model to the stocks obtained by direct inventories, by tuning the lifetime parameter of the model. However, direct inventories do not seem suitable to deal with paper products, as reliable data on the paper stocks are difficult to obtain and the paper stocks may change rapidly due to its short lifetime [12].

The criteria being used in the evaluation of the approaches for carbon accounting in wood products $[4,29]$ include technical aspects, of which some were discussed in this study, and policy aspects. In fact, different incentives or disincentives for sustainable forest management and for use of wood and wood products could be provided depending on the approach. For example, the atmospheric-flow approach encourages the exportation of wood, instead of its utilisation in the country. In addition, no incentive for sustainable forest management is given as the carbon contained in wood from non-sustainable forests can be exported, generating emissions which will be accounted for in another country. The stock-change approach favours the use of long-lived wood products in the country and stimulates sustainable forest management, in view of the expansion of the domestic stocks in forests and wood products.

\section{CONCLUSIONS}

The carbon sink provided by wood products in Portugal was estimated from 1990 to 2000 using the stock-change and the atmospheric-flow approaches. The carbon sequestration calculated by the stock-change approach has been increasing from $310 \mathrm{Gg} \mathrm{C} \mathrm{yr}^{-1}$, in 1990 , to $611 \mathrm{Gg} \mathrm{C} \mathrm{yr}^{-1}$, in 2000 . On the other hand, in the same period, the atmospheric-flow approach produced results varying from $322 \mathrm{Gg} \mathrm{C} \mathrm{yr}^{-1}$ to $783 \mathrm{Gg} \mathrm{C} \mathrm{yr}^{-1}$. The estimates of carbon sequestration with the atmosphericflow approach were larger than the ones obtained with the stock-change approach when there was a net export of carbon.

The sensitivity analysis demonstrated that the estimation method used in this study is significantly affected by the parameters related with the lifetime of the products (annual decay rates and fractions allocated to long-lived products), the carbon fraction in paper and paperboard and the biomass conversion factor. According to the sensitivity analysis, carbon sequestration under the stock-change approach may be, on average, overestimated in $65 \%$ or underestimated in $20 \%$. Under the atmosphericflow approach, it may be, on average, overestimated in $80 \%$ or underestimated in $43 \%$.

Acknowledgements: The authors are grateful to the FCT (Science and Technology Foundation - Portugal) for the financial support provided to the project "Portuguese wood industries: greenhouse gas fluxes and accounting methods for the evaluation of the global warming effect" (POCTI/CTA/35598/99) and for the Ph.D. scholarship granted to Ana Cláudia Dias (SFRH/BD/1084/2000).

\section{REFERENCES}

[1] AIMMP, As Indústrias da Fileira de Madeira e o PNAC - Contributo para o Cenário de Referência 2001, Associação das Indústrias de Madeira e Mobiliário de Portugal, Oporto, 2002 (in Portuguese).

[2] Arroja L., Dias A., Capela I., The role of Eucalyptus globulus forest and products in carbon sequestration, Clim. Change (2005) in press.

[3] Boyle C.A., Lavkulich L., Carbon pool dynamics in the Lower Fraser Basin from 1827 to 1990, Environ. Manage. 21 (1997) 443-455.

[4] Brown S., Lim B., Schlamadinger B., Evaluating Approaches for Estimating Net Emissions of Carbon Dioxide from Forest Harvesting and Wood Products, Meeting Report, Dakar, 5-7 May 1998, IPCC/OECD/IEA Programme on National Greenhouse Gas Inventories, 1998.

[5] Burschel P., Kürsten E., Larson B.C., Weber M., Present role of German forests and forestry in the national carbon budget and options to its increase, Water Air Soil Pollut. 70 (1993) 325-340.

[6] Castéra P., Nepveu G., Chantre G., Principaux facteurs de contrôle de la variabilité du bois chez le pin maritime (Pinus pinaster ait.), in: Actes du Ve Colloque Arbora, Bordeaux, 2-3 December 1999, 
Association pour la Recherche sur la Production Forestière et le Bois en Région Aquitaine, Bordeaux, 1999, pp. 91-101.

[7] Celpa, Boletim Estatístico da Indústria Papeleira Portuguesa, Associação da Indústria Papeleira, Lisbon (in Portuguese).

[8] DGF, Perfil Florestal, Direcção-Geral das Florestas, Lisbon, 1991 (in Portuguese).

[9] Divisão de Estudos Económicos - IPF, Mercado interno de matérias-lenhosas, Madeira 39 (1983) 15-21 (in Portuguese).

[10] FAO, FAOSTAT Forestry Data, Food and Agriculture Organization, http://apps.fao.org/page/collections?subset=forestry [06/06/03], 2003.

[11] Ferreira V.G., Pereira T.C., Seabra T., Portuguese National Inventory Report on Greenhouse Gases, 1990-2001, Submitted under the United Nations Framework Convention on Climate Change, Ministry for Urban Affairs, Land-Use Planning and the Environment, Amadora, 2003.

[12] Flugsrud K., Hoem B., Kvingedal E., Rypdal K., Estimating the Net Emission of $\mathrm{CO}_{2}$ from Harvested Wood Products - a Comparison between Different Approaches, Report 1831/2001, Norwegian Pollution Control Authority, Oslo, 2001.

[13] Ford-Robertson J., Robertson K., Sligh P., Implications of carbon accounting methods for harvested wood products in New Zealand, APPITA J. 52 (1999) 263-268.

[14] Gjesdal S.F.T., Flugsrud K., Mykkelbost T.C., Rypdal R., A Balance of Use of Wood Products in Norway, Report 96:04, Norwegian Pollution Control Authority, Oslo, 1996.

[15] Goes E., A Floresta Portuguesa: sua Importância e Descrição das Espécies de Maior Interesse, Portucel, Lisbon, 1991 (in Portuguese).

[16] Hashimoto S., Nose M., Obara T., Moriguchi Y., Wood products: potential carbon sequestration and impact on net carbon emissions of industrialized countries, Environ. Sci. Policy 5 (2002) 183-193.

[17] INE, Estatísticas do Comércio Externo, Instituto Nacional de Estatística, Lisbon (in Portuguese).

[18] INR, Plano Estratégico Sectorial de Gestão dos Resíduos Sólidos Urbanos, Instituto dos Resíduos, Lisbon, 1997 (in Portuguese).

[19] INR, Produção de Resíduos Sólidos Urbanos/2000, Instituto dos Resíduos, Lisbon, 2000 (in Portuguese).

[20] IPCC, Revised 1996 IPCC Guidelines for National Greenhouse Gas Inventories, Reporting Instructions, Vol. 1, IPCC WG I Technical Support Unit, Bracknell, 1996.

[21] IPCC, Revised 1996 IPCC Guidelines for National Greenhouse Gas Inventories, Workbook, Vol. 2, IPCC WG I Technical Support Unit, Bracknell, 1996.

[22] IPCC, Revised 1996 IPCC Guidelines for National Greenhouse Gas Inventories, Reference Manual, Vol. 3, IPCC WG I Technical Support Unit, Bracknell, 1996.

[23] IPCC, Good Practice Guidance and Uncertainty Management in National Greenhouse Gas Inventories, IPCC Technical Support Unit, Hayama, 2000.

[24] IPCC, Special Report on Land Use, Land-Use Change and Forestry, Cambridge University Press, Cambridge, 2000.

[25] Jaakko Pöyry Consulting, Usage and Life Cycle of Wood Products, NCAS Technical Report No. 8, Australian Greenhouse Office, Canberra, 1999.

[26] Jäkel U., Schwaiger H., Häger C., Kohlmaier G.H., Schlamadinger B., Spitzer J., European study of carbon in the ocean, biosphere and atmosphere: Biosphere. Modelling the carbon exchange between forests and the atmosphere: Development and use of a model to assess carbon balances of forest management and wood utilization strategies under current and future climate conditions, 1999.

[27] Karjalainen T., Kellomäki S., Pussinen A., Role of wood-based products in absorbing atmospheric carbon, Silva Fenn. 28 (1994), $67-80$.
[28] Lamlom S.H., Savidge R.A., A reassessment of carbon content in wood: variation within and between 41 North American species, Biomass Bioenergy 25 (2003) 381-388.

[29] Lim B., Brown S., Schlamadinger B., Carbon accounting for forest harvesting and wood products: review and evaluation of different approaches, Environ. Sci. Policy 2 (1999) 207-216.

[30] Micales J.A., Skog K.E., The decomposition of forest products in landfills, Int. Biodeter. Biodegr. 39 (1997) 145-158.

[31] Nabuurs G.J., Sikkema R., International trade in wood products: its role in the land use change and forestry carbon cycle, Clim. Change 49 (2001) 377-395.

[32] Nabuurs G.J., Schelhaas M.J., Mohren G.M.J., Field C.B., Temporal evolution of the European forest sector carbon sink from 1950 to 1999 , Glob. Change Biol. 9 (2003) 152-160.

[33] Pedroso M.M.A., A indústria de serração de madeiras, seu enquadramento nas indústrias florestais, Madeira 55 (1987) 9-13 (in Portuguese).

[34] Pingoud K., Savolainen I., Seppälä H., Greenhouse impact of the Finnish forest sector including forest products and waste management, Ambio 25 (1996) 318-326.

[35] Pingoud K., Perälä A.-L., Pussinen A., Carbon dynamics in wood products, Mitig. Adap. Strat. Glob. Change 6 (2001) 91-111.

[36] Pingoud K., Perälä A.-L., Pussinen A., Soimakallio S., Greenhouse Gas Impacts of Harvested Wood Products - Evaluation and Development of Methods, VTT Research Notes 2189, VTT Technical Research Centre of Finland, Espoo, 2003.

[37] Poker J., Dieter M., Thoroe C., Integration of Harvested Wood Products into Accounting Approaches of the Carbon Dioxide Cycle in the Forestry Sector, Working Paper 2002/03, Institute for Economics, Federal Research Centre for Forestry and Forest Products, Hamburg, 2002.

[38] Quercus, Caracterização dos Resíduos Sólidos Urbanos e Inventariação dos Locais de Deposição em Portugal, Quercus-Associação Nacional de Conservação da Natureza, Lisbon, 1995.

[39] Reyes G., Brown S., Chapman J., Lugo A.E., Wood Densities of Tropical Tree Species, General Technical Report SO-88, United States Department of Agriculture, Forest Service, Southern Forest Experiment Station, New Orleans, 1992.

[40] Sikkema R., Schelhaas M.J., Nabuurs G.J., International Carbon Accounting of Harvested Wood Products: Evaluation of Two Models for the Quantification of Wood Product Related Emissions and Removals, Contribution of The Netherlands to the International Collaborative Study, Report No. 410200111, National Institute of Public Health and the Environment, Bilthoven, 2002.

[41] Skog K.E., Nicholson G.A., Carbon sequestration in wood and paper products, in: Joyce LA., Birdsey R. (Eds.), The Impact of Climate Change on America's Forests: a Technical Document Supporting the 2000 USDA Forest Service RPA Assessment, Gen. Tech. Rep. RMRS-GTR-59, Department of Agriculture, Forest Service, Rocky Mountain Research Station, Fort Collins, 2000, pp. 79-88.

[42] Soalleiro R.R., Gozález J.G.A., González M.C., Vásquez P.M., Alonso P.V., Rosales M.G., Zorrilla P.R., Alonso G.V., Manual Técnico de Selvicultura del Pino Pinaster, Escuela Politécnica Superior de Lugo, Lugo, 1997 (in Spanish).

[43] Valente C.A., Sousa A.P.M., Furtado F.P., Carvalho A.P., Improvement program for Eucalyptus globulus at Portucel: technological component, APPITA J. 45 (1992) 403-407.

[44] Werner F., Taverna R., Hofer P., Richter K., Carbon pool and substitution effects of an increased use of wood in buildings in Switzerland: first estimates, Ann. For. Sci. 62 (2005) 889-902.

[45] Winjum J.K., Brown S., Schlamadinger B., Forest harvests and wood products: sources and sinks of atmospheric carbon dioxide, For. Sci. 44 (1998) 272-284. 